\title{
Perbedaan Efek Paparan Pestisida Kimia dan Organik terhadap Kadar Glutation (GSH) Plasma pada Petani Padi
}

\author{
Ain Yuanita Insani ${ }^{1}$, Ancah Caesarina Novi Marchianti ${ }^{2}$, Septa Surya Wahyudi ${ }^{3}$ \\ ${ }^{1}$ Program Studi Pendidikan Dokter, Fakultas Kedokteran Universitas Jember \\ ${ }^{2}$ Laboratorium Ilmu Kesehatan Masyarakat, Fakultas Kedokteran Universitas Jember \\ ${ }^{3}$ Laboratorium Anatomi, Fakultas Kedokteran Universitas Jember \\ Corresponding author : aininsani@gmail.com
}

Info Artikel:Diterima Januari 2018 ; Disetujui April 2018 ; Publikasi Oktober 2018

\begin{abstract}
ABSTRAK
Latar belakang:Serangan hama dan penyakit tanaman semakin meluas, sehingga para petani tidak dapat menghindari penggunaan pestisida kimia. Pestisida kimia bersifat polutan dan mengakibatkan terbentuknya radikal bebas yang dapat menyebabkan kerusakan organ. WHO memperkirakan ada 1,5 juta kasus keracunan pestisida terjadi pada pekerja di sektor pertanian. Tubuh membutuhkan antioksidan untuk menanggulangi radikal bebas akibat pestisida kimia. Salah satu antioksidan yang sering diukur untuk melihat dampak peningkatan radikal bebas adalah glutation(GSH). Penelitian ini bertujuan untuk mengetahui perbedaan efek paparan pestisida kimia dan organik terhadap kadar GSH plasma pada petani padi.

Metode:Jenis penelitian yang digunakan adalah analitik observasional dengan rancangan penelitiancross sectional. Penelitian ini menggunakan sampel 30 orang, 15 orang petani organik di Desa Lombok Kulon Kecamatan Wonosari Kabupaten Bondowoso dan 15 orang petani anorganik di Desa Dawuhan Kecamatan Tenggarang Kabupaten Bondowoso. Pengambilan sampel darah dilakukan di vena mediana cubiti, selanjutnya dilakukan pengukuran kadar GSH plasma menggunakan metode Elman. Uji statistika dilakukan dengan menggunakan uji Unpaired T-test.

Hasil:Hasil penelitian ini menunjukkan bahwa terdapat perbedaan yang signifikan antara kadar GSH plasma petani anorganik dan organik $\mathrm{p}<0.05$. Petani anorganik memiliki rata-rata kadar GSH plasma lebih rendah dibandingkan dengan rata-rata kadar GSH plasma petani organik. Hal tersebut terjadi karena para petani anorganik mendapatkan paparan polutan berlebih dari zat-zat kimia dalam pestisida kimia sedangkan petani organik menggunakan bahan alami sehingga tidak menimbulkan residu dalam tubuh.

Simpulan: Terdapat perbedaan yang signifikan antara kadar GSH plasma pada kelompok petani anorganik dan kelompok petani organik. Kadar GSH plasma petani anorganik lebih rendah dibandingkan dengan kadar GSH plasma petani organik.
\end{abstract}

Kata kunci:pestisida kimia; pestisdia organik; glutation (GSH) plasma

\section{ABSTRACT}

Title: The Difference Effect of Chemical and Organic Pesticides Exposure to Plasma Glutathione (GSH) on Rice Farmers

Background:Pests and plant diseases are widespread in agriculture so the use of chemical pesticides can not avoid. Pesticides are pollutants which forming free radicals and cause organ damage. WHO estimates that 1.5 million cases of pesticide poisoning occur in agricultural workers. The body needs antioxidant to cope free radicals due to chemical pesticides. GSH is one of antioxidants often measured to see the effects of increased free radicals in the body. This study aims to determine the differences effect of chemical and organic pesticide exposure on plasma glutathione (GSH) levels in rice farmers.

Methods:The type of this research is observational analytics with cross sectional design. This study used 30 people as sample, 15 people organic farmers in the Desa Lombok Kulon, Kecamatan Wonosari, Bondowoso and 15 people inorganic farmers in Desa Dawuhan, Kecamatan Tenggarang, Bondowoso. Blood sampling was done 
in mediana cubiti vein, then measured of plasma GSH using Elman method. The statistical test was done by using Unpaired T-test.

Results: The resulf of this research showed that there is a significant difference between plasma GSH level of inorganic farmer and organic farmer $p<0.05$. The average plasma GSH level of inorganic farmersare lower than average plasma GSH levels of organic farmers. This result is caused by excessive pollutants of chemicals contained in the pesticide exposed inorganic farmers while the group of organic farmers used natural ingredients in the pesticide so it did not makes residues in the body of farmers.

Conclusion:Based on this, it is advisable for farmers to be more wise to use chemical pesticides in accordance with established rules and better recommended to replace the use of chemical pesticides with organic pesticides.

Keywords:chemical pesticides; organic pesticide; plasma glutathione (GSH)

\section{PENDAHULUAN}

Pestisida kimia merupakan bahan beracun yang sangat berbahaya bagi kesehatan dan lingkungan. Hal ini disebabkan pestisida bersifat polutan dan menyebarkan radikal bebas yang dapat menyebabkan kerusakan organ tubuh seperti mutasi gen dan gangguan syaraf pusat. Disamping itu residu kimia yang beracun tertinggal pada produk pertanian dapat memicu kerusakan sel, penuaan dini dan munculnya penyakit degeneratif. ${ }^{1} \quad$ Pestisida juga dapat mengakibatkan stress oksidatif.Penelitian sebelumnya yang dilakukan oleh Surajudeenpada tahun 2014menjelaskan bahwa ada hubungan positif antara tingkat paparan pestisida dengan timbulnya stress oksidatif. ${ }^{2}$ Berdasarkan survei lokasi, diketahui bahwa Desa Dawuhan Kecamatan Tenggarang Kabupaten Bondowoso, intensitas penyemprotan pestisidanya sangat tinggi dikarenakan Desa Dawuhan merupakan daerah dengan tingkat serangan hama dan penyakit paling tinggi di Kabupaten Bondowoso. Serangan hama penyakit yang tinggi mengakibatkan banyak formulator pestisida masuk ke desa ini dan masyarakat pun terpengaruh untuk menggunakan pestisida. Banyak kasus petani yang merasa pusing dan mual setelah menyemprot, bahkan sampai tidak sadarkan diri di lahan karena sering melakukan penyemprotan pestisida.

Tubuh membutuhkan antioksidan untuk menanggulangi radikal bebas. Antioksidan diperoleh dari luar tubuh (makanan) atau diproduksi oleh tubuh sendiri (endogen). Contoh antioksidan endogen adalah superoksida dismutase, glutation (GSH), katalase dan glutation peroksidase. Salah satu antioksidan yang sering diukur untuk melihat dampak peningkatan radikal bebas dalam tubuh adalah GSH. Glutationakan berinteraksi denganreactive oxigen species(ROS) dengan cara bertindak sebagai reseptor elektron dan menghidrolisis ROS. Akibatnya akan terbentuk 2 jenis glutationyaitu GSH dan glutation disulfida (GSSG). Reduced glutathione yang tersisa akan terus berinteraksi dengan ROS hingga jumlahnya semakin berkurang sedangkan GSSG akan langsung dimetabolisme di hepar. GSH juga akan dikonjugasikan dengan pestisida yang merupakan xenobiotik elektrofilik oleh enzim glutathion $s$ transferase dan akan terbentuk asam merkapturat yang selanjutnya dibuang melalui urin..$^{3,4,5,6,7}$
Timbulnya stres oksidatif akibat paparan pestisida kimia telah banyak diteliti, namun belum ada penelitian mengenai efek pestisida organik terhadap timbulnya stres oksidatif. Desa Lombok Kulon Kecamatan Wonosari Kabupaten Bondowoso mengembangkan pertanian organik sejak tahun 2010 dan telah mendapatkan sertifikat organik dari Lembaga Sertifikat Organik Seloliman pada tahun 2013. Peneliti ingin mengetahui apakah ada perbedaan efek paparan pestisida kimia dan organik terhadap timbulnya stres oksidatif yang diukur dari kadar GSH plasma para petani. Jika terdapat perbedaan efek, dalam hal ini paparan pestisida organik tidak terbukti menimbulkan stres oksidatif, peneliti berharap hasil penelitian ini dapat dijadikan salah satu acuan untuk menyarankan para petani beralih menggunakan pestisida organik yang lebih aman baik untuk lingkungan maupun kesehatan tubuh dengan tetap mempertahankan kualitas produksi pertanian.

\section{MATERI DAN METODE}

Jenis penelitian yang digunakan dalam penelitian ini adalah analitik observasional dengan rancangan penelitian yang digunakan adalah cross sectional. Penelitian ini bertujuan untuk mengetahui perbedaan efek paparan pestisida kimia dan organik terhadap kadar glutation (GSH) plasma pada petani padi. Penelitian ini menggunakan sampel 30 orang sampel dengan rincian 15 orang petani organik dari Desa Lombok Kulon Kecamatan Wonosari Kabupaten Bondowoso dan 15 orang petani anorganik dari Desa Dawuhan Kecamatan Tenggarang Kabupaten Bondowoso. Teknik pengambilan sampel menggunakan metode purposive sampling berdasarkan kriteria inklusi yaitu berusia 20-50 tahun, telah bekerja sebagai penyemprot pestisida kimia selama $\geq 5$ tahun (petani anorganik), telah bekerja sebagai penyemprot pestisida organik selama $\geq 5$ tahun (petani organik), dan memiliki indeks massa tubuh normal; dan kriteria ekslusi yaitu menderita penyakit kronik dan sedang dalam keadaan sakit (menderita infeksi).

Pengambilan sampel darah dilakukan pada vena mediana cubiti oleh tenaga yang berkompeten, selanjutnya sampel darah dimasukkan dalam tabung anti koagulan na-sitrat selanjutnya disentrifugasi dan diambil plasma darahnya. Ditambahkan 8,9 mL dapar 
fosfat $\mathrm{pH} 8,0$ dan $1 \mathrm{ml}$ TCA 5\% ke dalam $250 \mu \mathrm{L}$ plasma darah lalu dikocok hingga homogen. Kemudian larutan disentrifugasi pada kecepatan 3000 rpm selama 5 menit. Dari larutan tersebut diampil 4 mL supernatan dan ditambahkan $50 \mu \mathrm{L}$ larutan DTNB (39,9 mg DTNB dilarutakan dalam $10 \mathrm{~mL}$ dapar fosfat $\mathrm{pH}$ 7,0). Sisa supernatan digunakan sebagai blanko. Pada menit ke-5 diukur absorbansi sampel terhadap blanko pada panjang gelombang $412 \mathrm{~nm}$.

Analisis data untuk mengetahui perbedaan kadar GSH antar kedua kelompok menggunakan uji unpaired t-test dengan tingkat pemaknaan $\mathrm{p}<0,05$. Software yang digunakan adalah program komputer pengolah statistik Statistical Package forSocialScience (SPSS) 16.0.Penelitian ini juga sudah mendapatkan persetujuan etik dari Fakultas Kedokteran Universitas Jember.

\section{HASIL DAN PEMBAHASAN}

Didapatkan 30 sampel yang memenuhi kriteria inklusi dan kriteria eksklusi. Keseluruhan sampel pada masing-masing kelompok adalah petani laki-laki dengan indeks massa tubuh normal serta masih mengabaikan penggunaan alat pelindung diri. Karakteristik umum sampel dapat dilihat pada Tabel 1. Daftar pestisida yang digunakan petani organik dan anorganik dapat dilihat pada tabel 2 .

Kadar normal GSH plasma manusia berkisar antara 34 - $42 \mathrm{mg} / \mathrm{dL}$. Rata-rata kadar GSH pada petani organik dan anorganik dapat dilihat pada Gambar 1. Hasil uji unpaired t-test kadar GSH petani organik dan petani anorganik dapat dilihat pada Tabel 3 .

Tabel 1.Distribusi karakteristik umum sampel

\begin{tabular}{lcccc}
\hline Karakteristik Sampel & $\begin{array}{c}\text { Jumlah Petani } \\
\text { Organik }(\mathrm{n})\end{array}$ & $\begin{array}{c}\text { Persentase } \\
(\%)\end{array}$ & $\begin{array}{c}\text { Jumlah Petani } \\
\text { Anorganik }(\mathrm{n})\end{array}$ & $\begin{array}{c}\text { Persentase } \\
(\%)\end{array}$ \\
\hline Usia & & & & \\
$25-40$ & 10 & 66,7 & 10 & 66,7 \\
$\quad 51-50$ & 5 & 33,3 & 5 & 33,3 \\
Kebiasaan Merokok & 6 & 40,0 & 6 & 40,0 \\
$\quad$ Tidak & 3 & 20,0 & 3 & 20,0 \\
$\quad(1-10)$ / hari & 6 & 40,0 & 6 & 40,0 \\
$\quad(11-24)$ / hari & & & & \\
Riwayat Menyemprot & 0 & 0,0 & 1 & 6,7 \\
$<6$ tahun & 15 & 100 & 7 & 46,7 \\
6-10 tahun & 0 & 0,0 & 7 & 46,7 \\
10 tahun & & & & \\
Frekuensi Menyemprot & 0 & 0,0 & 2 & 13,3 \\
5-9 kali & 15 & 100 & 11 & 73,4 \\
10-14 & 0 & 0,0 & 2 & 13,3 \\
14 & & & & \\
Tingkat Pendidikan & 4 & 26,7 & 5 & 33,3 \\
SD & 7 & 46,7 & 6 & 20,0 \\
SMP & 2 & 13,3 & 3 & 0,0 \\
SMA & 1 & 6,7 & 0 & 6,7 \\
D4 & 1 & 6,7 & 1 & \\
S1 & & & & \\
\hline
\end{tabular}

Tabel 2. Pestisida kimia yang digunakan oleh petani anorganik dan pestisida organik yang digunakan oleh petani organik

\begin{tabular}{ll}
\hline \multicolumn{1}{c}{ Pestisida Kimia } & \multicolumn{1}{c}{ Pestisida Organik } \\
\hline Decis 25 EC (Insektisida golongan & Daun Mahoni (Insektisida) \\
piretroid) & Daun Sirsat (Insektisida) \\
Rizotin 100 EC (Insektisida golongan & Daun Kluwih (Insektisida) \\
piretroid) & Brotowali (Insektisida) \\
Round Up 486 SL (Insektisida & Buah Maja (Insektisida) \\
golongan organofosfat) & Daun Bintaro (Insektisida) \\
Amistar Top 325 SC (Fungisida) & Daun Mahkota (Insektisida) \\
Filia 525 SE (Fungisida) & Daun Mimba (Insektisida) \\
Score 250 EC (Fungisida) & Daun Mindi (Insektisida) \\
Ally Plus 77 WP (Herbisida) & Bawang Putih (Fungisida) \\
& Meniran (Fungisida) \\
& Bawang Merah (Fungisida) \\
& Empon-empon (Fungisida) \\
& Cabai (Fungisida) \\
\end{tabular}




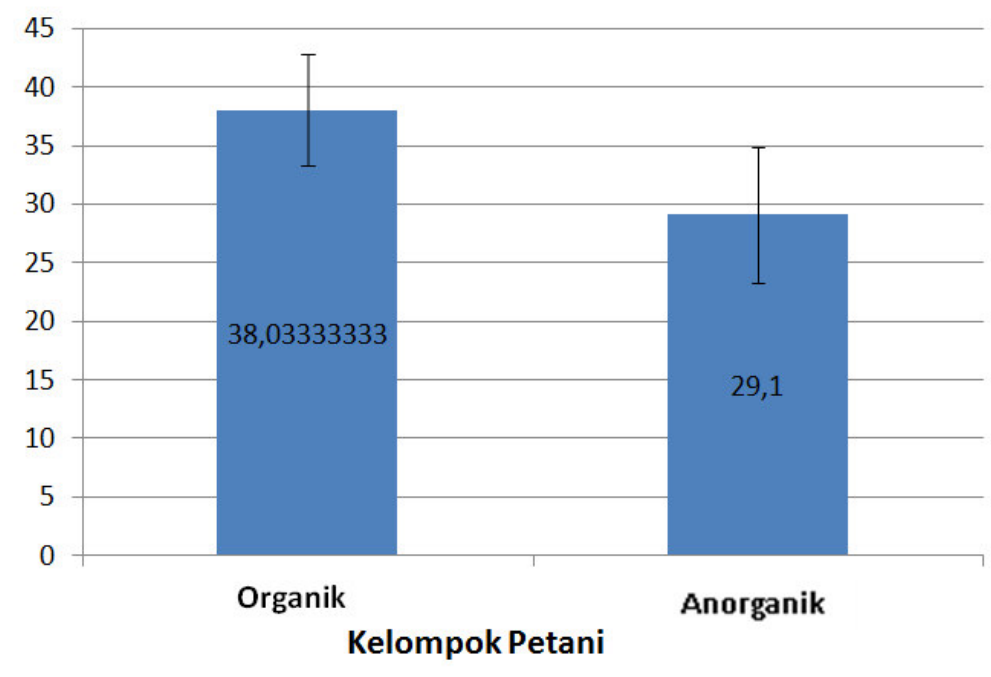

Gambar 1. Rata-Rata Kadar GSH pada Petani Anorganik dan Organik

Tabel 3. Hasil uji unpaired t-test kadar GSH petani organik dan anorganik

\begin{tabular}{lccc}
\hline & $\mathbf{N}$ & Rerata \pm SD $(\mathbf{m g} / \mathbf{d L})$ & $\boldsymbol{P}$ \\
\hline Petani Organik & 15 & $38,03 \pm 4,77$ & $<0,001$ \\
Petani Anorganik & 15 & $29,10 \pm 5,78$ & \\
\hline
\end{tabular}

Karakteristik sampel dari masing-masing kelompok adalah serupa sehingga diharapkan tidak terjadi bias berdasarkan status gizi, usia, riwayat merokok, riwayat menyemprot, frekuensi menyemprot, dan tingkat pendidikan para petani. Berdasarkan data yang diperoleh dari penelitian ini, rata-rata kadar GSH plasma pada kelompok petani organik adalah $38,03 \pm 4,77 \mathrm{mg} / \mathrm{dL}$, nilai tersebut masih dalam rentang kadar normal GSH yaitu $34-42$ $\mathrm{mg} / \mathrm{dL}$. Pada kelompok petani anorganik rata - rata kadar GSH plasma adalah 29,10 $\pm 5,78 \mathrm{mg} / \mathrm{dL}$, oleh karena itu rata-rata kadar GSH plasma pada kelompok petani anorganik dapat dikatakan tidak normal. Hal tersebut terjadi karena pada kelompok petani anorganik, para petani mendapatkan paparan polutan berlebih dari zat-zat kimia yang terdapat dalam pestisida, seperti diazinon, deltamethrin, dan sipermethrin. Zat-zat tersebut masuk ke dalam tubuh dan bereaksi dengan sitokrom P450 monooksigenase dan akan menghasilkan radikal bebas. Radikal bebas akan masuk dalam siklus respiratori dan akan terjadi reaksi antara radikal bebas dan SOD untuk membentuk $\mathrm{H}_{2} \mathrm{O}_{2}$ selanjutnya enzim katalase dan glutathione peroksidase mereduksi $\mathrm{H}_{2} \mathrm{O}_{2}$ menjadi $\mathrm{H}_{2} \mathrm{O}$ dan $\mathrm{O}_{2}$. Dalam proses tersebut diperlukan adanya 2 molekul GSH untuk menyumbangkan elektronnya sehingga GSH akan berubah menjadi bentuk teroksidasi (GSSG). ${ }^{8}$ Hal ini yang menyebabkan kadar GSH pada penyemprot pestisida kimia lebih rendah dibandingkan dengan penyemprot pestisida organik. Pada kelompok petani organik, bahan yang digunakan untuk membasmi hama dan penyakit tanaman adalah fermentasi dari bagian-bagian tanamna yang banyak di temui di desa seperti daun sirsat, daun kluwih, daun mimba, buah mojo dan sebagainya. Pestisida yang digunakan keseluruhan bahan alami sehingga tidak menimbulkan residu dalam tubuh petani maupun ke dalam lingkungan. Berdasarkan hal tersebut, dapat diketahui bahwa pada petani organik tidak terjadi penurunan kadar GSH plasma akibat paparan pestisida organik. Bahan alami dapat melindungi diri dari ROS dan dapat menanggulangi stres oksidatif dalam tubuh. ${ }^{9}$

Hasil uji hipotesis menggunakan uji unpaired t-test menunjukkan nilai $\mathrm{p}<0,001(<0,05)$. Hasil tersebut menunjukkan bahwa terdapat perbedaan kadar GSH plasma yang signifikan antara kelompok petani organik dan kelompok petani anorganik. Hasil uji beda ini didukung oleh penelitian sebelumnya yang menyatakan adanya perbedaan kadar GSH pada penyemprot pestisida kimia dan orang sehat yang bukan penyemprot pestisida kimia dengan nilai $\mathrm{p}<0,001 .{ }^{10}$ Penelitian yang lain menyebutkan bahwa kadar GSH pada penyemprot pestisida kimia lebih rendah dibandingkan dengan kontrol, yaitu orang sehat yang bukan penyemprot pestisida kimia. ${ }^{2,11}$ Masuknya zat racun dari pestisida kimia dapat memicu adanya stres oksidatif. Saat terjadi stress oksidatif terjadi pelepasan 2 molekul GSH untuk menangkal radikal bebas sehingga, ketika stres oksidatif meningkat akibat akumulasi zat-zat kimia dari pestisida maka molekul GSH yang digunakan semakin banyak dan berakibat pada penurunan GSH.

Petani yang telah bekerja sebeagai penyemprot pestisida kimia selama 3-8 tahun telah terjadi penumpukan radikal bebas yang mengakibatkan terjadinya stres oksidatif. Hal tersebut ditandai dengan penurunan kadar GSH yang signifikan $(\mathrm{p}<0,001)$. 
Pada penelitian ini juga juga didapatkan terjadi peningkatan aktifitas glutathione-S-transferase (GST) yang signifikan $(\mathrm{p}<0.001)$. Parameter lain seperti superoxide dismutase (SOD), catalase (CAT), dan glutathione peroxidase (GPx) juga telah mengalami peningkatan aktivitas yang signifikan $(\mathrm{p}<0,01)$ dibandingkan dengan kontrol yang menggunakan orang sehat tanpa paparan pestisida kimia. ${ }^{10}$ Penelitian lain menjelaskan bahwa pada petani penyemprot yang mengalami paparan kronik pestisida kimia seperti karbamat, ditiokarbamat, organofosfat, pirethroid dan neonicotinoid telah terjadi penumpukan radikal bebas, dibuktikan dengan terjadi penurunan kadar superoxide dismutase (SOD) dan glutathione reductase $(G R)$ yang signifikan $(\mathrm{p}<0,001)$. Pada paparan akut pestisida kimia telah terjadi pula penumpukan radikal bebas, yang dibuktikan dengan terjadi penurunan kadar superoxide dismutase (SOD) yang signifikan $(\mathrm{p}<0,001) .{ }^{11}$ Berdasarkan hal tersebut, disarankan pada petani untuk semakin bijak menggunkan pestisida kimia sesuai aturan yang telah ditetapkan dan lebih baik untuk mengganti penggunaan pestisida kimia dengan pestisida organik.

Penelitian ini masih memiliki banyak keterbatasan dan kekurangan, antara lain belum memperhitungkan jarak waktu terakhir penyemprotan pestisida oleh petani dan pengambilan sampel darah serta hanya melakukan satu pengukuran antioksidan yaitu glutation (GSH) sehingga tidak dapat diketahui bagaimana pengaruh paparan pestisida kimia dan organik terhadap biomarker lain yang menunjukkan terjadinya stres oksidatif. Oleh karena itu diperlukan penelitian lebih lanjut dengan memperhitungkan jarak waktu penyemprotanpestisida dan pengambilan sampel darah serta menggunakan biomarker yang lebih lengkap seperti SOD, GPx, GST, GR, vitamin E, vitamin $\mathrm{C}$ dan lain sebagainya.

\section{SIMPULAN}

Berdasarkan hasil penelitian yang telah dilakukan didapatkan kesimpulan sebagai berikut: Terdapat perbedaan yang signifikan antara kadar GSH plasma pada kelompok petani anorganik dan kelompok petani organik. Kadar GSH plasma petani anorganik lebih rendah dibandingkan dengan kadar GSH plasma petani organik. Rata-rata nilai kadar GSH plasma kelompok petani organik masih dalam rentang batas normal $(38,03 \pm 4,77 \mathrm{mg} / \mathrm{dL})$. Ratarata nilai kadar GSH plasma kelompok petani anorganik berada dibawah rentang batas normal $(29,10 \pm 5,78 \mathrm{mg} / \mathrm{dL})$. Pestisida kimia yang digunakan oleh petani anorganik di Desa Dawuhan Kecamatan Tenggarang Kabupaten Bondowoso adalah insektisida golongan piretroid dan organofosfat, fungisida dan herbisida yang penggunaannya tidak sesuai dengan aturan yang telah ditetapkan. Pestisida organik yang digunakan oleh petani organik di Desa Lombok Kulon Kecamatan Wonosari Kabupaten Bondowoso adalah yang terbuat dari fermentasi bahan-bahan organik seperti dedaunan dan sisa-sisa hewan yang dibuat sendiri oleh para petani dengan penggunaan sesuai aturan.

\section{DAFTAR PUSTAKA}

1. Kumar LP, Panneerselvam N. Toxic Effects of Pesticides: A Review on Cytogenetic Biomonitoring Studies. Medicine and Biology. 2008, 15(2): 46-50.

2. Surajudeen YA, Sheu RK, Ayokulehin KM, Olatunbosun AG. Oxidative stress indices in Nigerian pesticide applicators and farmers occupationally exposed to organophosphate pesticides. International Journal of Applied and Basic Medical Research. 2014, 4(1):37-41.

3. Main PAE, Angley MT, O'Doherty CE, Thomas $\mathrm{P}$, Fenech $\mathrm{M}$. The potential role of the antioxidant and detoxification properties of glutathione in autism spectrum disorders: a systematic review and meta-analysis.Nutrition and Metabolism 2012, 9: 35 .

4. Kalpravidh RW, Tangjaidee T, Hatairaktham S, Charoensakdi R, Panichkul N, Siritanaratkul N, and Fucharoen, S. Glutathione Redox System in $\beta$-Thalassemia/Hb E Patients. The Scientific World Journal 2013:1-7.

5. Khan H, Khan MF, Khan BA, Wahab A, Jan SU, Mukhtair M, Ullah N, Haque N, Farid A. Oxidation of glutathione (GSH) in blood plasma due to oxidative stressors: A case study of silver. Journal of Pharmacy and Pharmacology 2012, 6(21): 1502-1507.

6. Birben E, Sahiner UM.,Sackesen C,Erzurum S, dan Kalayci, O. Oxidative Stress and Antioxidant Defense.WAO Journal 2012, 5:9-19.

7. Adesanoye, OA, Farombi EO. In Vitro Antioxidant Properties of Methanolic Leaf Extract of Vernonia Amygdalina Del. Niger $J$ Physiol Sci 2014, 29: 91-101.

8. Hinkley GK, Roberts SM. Insecticides and Herbicides. Springer International Publishing Switzerland. 2015.

9. Chen W, Jia Z, Pan MH, Babu PVA. Natural Products for the Prevention of Oxidative StressRelated Diseases: Mechanisms and Strategies. Oxidative Medicine and Cellular Longevity 20152016: 2.

10. Sharma RK, Upadhyay G, Shiddiqi NJ, Sharma B. Pesticides-induced biochemicalalterations in occupational NorthIndian suburban population. Human and Experimental Toxicology 2013: 1-15.

11. Rastogi SK, Satyanarayan PVV, Ravishankar D, Tripathi SA. Study on oxidative stress and antioxidant status of agricultural workers exposed to organophosphorus insecticides during spraying. Indian Journal of Occupational and Environmental Medicine 2009 Desember; 13(3): 131-134. 